\title{
An Experimental Study: Multimedia Reading Materials on Teaching Reading Comprehension
}

\author{
Siswandi \\ State Islamic University of Sultan Syarif Kasim Riau, Indonesia \\ siswandi@uin-suska.ac.id
}

\begin{abstract}
The main focus of this research is to investigate whether there was a significant effect of using Multimedia Reading Materials on students' reading comprehension of narrative text at SMA Negeri 12 Pekanbaru. This research had two variables, Multimedia Reading Materials as an independent variable and students' reading comprehension as a dependent variable. This research was a quasi-experimental research. The writer selected two classes from total eleven classes by using cluster random sampling technique: experimental and control class. There were 70 students as sample out of 391 students. In collecting the data, the writer used multiple choice and short-answer question test. In analyzing the data, the writer used independent sample t-test formula calculated by using SPSS 25 version continued by using eta-square formula. Based on the analysis of ttest Formula, the sig. value is 0.000 . It could be stated that $0.000<0.05$. Then, the effect size is 0.41 categorized into moderate level. The writer concluded that there is significant effect of using Multimedia Reading Materials on students' reading comprehension of narrative text at SMA Negeri 12 Pekanbaru. And the biggest effect was occurred on the fourth component of reading comprehension that is identifying the meaning of words where the effect size is 0.14 categorized into large effect.
\end{abstract}

Key words: Multimedia, Reading Materials, Reading comprehension, Narrative text. 


\section{A. Introduction}

Reading is one of the important skills in learning English. it helps the students grow mentally, emotionally and psychologically. Every book gives you an opportunity to learn new things and explore new ideas. Reading books increases your knowledge and makes you smarter. According to Richards \& Schmidt (2010), reading is the processes by which the meaning of a written text is understood. In reading activity, students should be able to comprehend meaning of texts to get information and also knowledge from texts. Thus, it can be concluded that readers not only should know the meaning of words but also be able to comprehend the meaning contained in texts.

Moreillon (2007) stated that reading is making meaning from print and from visual information. It means that in reading activity, students should be able to get information from texts that can be in printed or visual forms. According to Patel \& Jain (2008) reading is an active process which consists of recognition and comprehension skill. Reading is an important activity in life with which one can update his/her knowledge. Reading skill is an important tool for academic success. So, reading skill is an important tool to update knowledge for the success by comprehending texts.

Therefore, the purpose of teaching reading in classroom is to develop students' ability to read, get the idea, understand texts written in English, update their knowledge and get success in academic. In order to achieve the goal of reading in classroom, teacher should be able to teach students effectively and efficiently. So, teacher has to use appropriate strategy, technique and tools or media in teaching reading.

Based on the preliminary research at State Senior High School 12 Pekanbaru, teacher still use conventional media in teaching and learning process. Teacher uses textbook to explain the materials. In consequence, students are not interested in learning reading comprehension which can influence their reading comprehension score. The passing grade is 78 . There were only 8 students had score above the passing grade and the rest got score below the passing grade. It means that only 8 students passed the reading test and the rest did not.

On the other words, the students had some problems in reading comprehension. The problems that still faced by the students are indicated in some symptoms; some of students were not able to identify topic, specific information, generic structures, meaning of words and communicative purpose of texts.

In order to solve students' problem in reading comprehension, there are many ways that can be used by teacher, one of them is using multimedia. Multimedia technology has important roles in learning process. Rai (2014) in his paper said that multimedia reading materials and environments have an edge over textbooks as they offer a variety of flexible supports including text-to-speech, voice recognition, animation, music and sound effects, embedded dictionaries, linked videos to 
boost background knowledge and vocabulary, study tools such as highlighters and annotation capabilities, and animated agent tutors.

In creating multimedia reading materials, the writer used one application called Macromedia Flash. Saputra \& Tiarina (2013) on their research said that Macromedia Flash is combination of learning concept with the audiovisual technology capable of generating new features that can be used in education. Hosea (2006) also stated that Flash is also used to create stand-alone CDROMS and presentations, animation for $\mathrm{TV}$, content for PDAs, interactive television, kiosks and mobile phones. So, Macromedia Flash is kind of interactive multimedia which include animation, audiovisual technology and can be used to create presentation in education.

Multimedia is very useful in learning English. It can increase the students' interest in reading and improve their reading comprehension. Teachers instructors and learners are helped by using media to achieve the learning goals (Pandey, 2014). Therefore, the writer considers that multimedia reading materials which are created by using Macromedia Flash can be useful, more effective, interactive and interesting in teaching reading.

The problems of this research can be formulated into the following questions: Is there any significant effect of using multimedia reading materials on students' reading comprehension at State Senior High School 12 Pekanbaru? And on which component of reading comprehension does the use of multimedia reading materials have the biggest effect on students' reading comprehension of narrative texts?

Based on the formulation of the problems above, this research is necessary to be carried out in order to achieve the objectives of the research as follows: first, to find out whether there is or not any significant effect of using multimedia reading materials on students' reading comprehension at Senior High School 12 Pekanbaru. Then, to find out on which component of reading comprehension does the use of multimedia reading materials have the biggest effect on students' reading comprehension of narrative text.

\section{B. The Theoretical Framework}

Reading is one of the main skills that should be mastered by language learners. The goal of reading is to get information by comprehending texts. As EFL learners, it is important to have good reading comprehension. According to Tierney (as cited in Karbalaei, 2010) reading is specifically the basic goal for ESL/EFL students to gain an understanding of the world and of themselves, enabling them to think about and react to what they read. In accordance with this statement, Grabe (1991) pointed out that reading is an essential skill and probably the most important skill for second language learners to master in academic contexts.

Anderson (2003) also stated that the mastery of reading skill could help EFL learners achieve success not only in English learning, but also in other content-based classes where English reading proficiency was required. Reading is an important skill to update knowledge. Learners will get any information needed by reading and 
understanding book, magazine, newspaper, and other reading materials.

By considering the fact, EFL learners need reading comprehension skill more than other skills in their academic studies. Indonesian education curriculum also provides reading as one skill that should be mastered by students. Widiati \& Cahyono (2006) pointed out that EFL reading skill become an important element of the establishment of English curriculums of secondary and tertiary schools (both English and nonEnglish departments) in Indonesia. For instance, in English formative test, most schools provide reading comprehension test to measure students' achievement. Therefore, most Indonesian students who have limited exposure to oral English communication, reading becomes the first skill to develop proficiency in the language". Thus, reading comprehension is the most important skill for EFL learners. By having good reading comprehension skills, learners will be able to achieve success in all academic studies and develop proficiency in the language.

Nowadays, the term multimedia cannot be separated with technology. "Multimedia refers to a technology for presenting material in both visual and verbal forms" (Mayer, 2005). In line with this statement, Richards \& Schmidt (2010) defined multimedia as computer mediated technologies that enable people to access and use data in a variety of forms: text, sound, and still and moving images. Thus, multimedia is the combination of text, sound, and still and moving images which is presented by using computer technology.

Mayer (2005) in his book also stated: "The term multimedia can be viewed in three ways-based on the devices used to deliver an instructional message (i.e., the delivery media), the representational formats used to present the instructional message (i.e., the presentation modes), or the sense modalities the learner uses to receive the instructional message (i.e., sensory modalities)." This statement means that the term multimedia has three meanings based on the points of view; delivery media, presentation modes and sensory modalities. In delivery media, it focuses on devices used to deliver information such as computer, projectors, amplified speakers, etc. In presentation modes, it focuses on the way materials represented. Then, in sensory modalities it means there are two or more sensory systems in the learner are involved; focusing on codes used to represent knowledge in learners' informationprocessing systems and sensorymodalities view focuses on the sensory receptors the learner uses to perceive the incoming material.

In order to use or create multimedia materials in the process of teaching and learning, there are many software can be used: BuildAbility, HyperStudio, Microsoft Power Point, Macromedia Flash, etc. Then, in this study, the writer will use Macromedia Flash to create multimedia materials.

\section{Research Design}

This research was an experimental research. According Gay et.al., (2012), experimental research is the only type of the research that can test hypotheses to establish cause-effect relationship. In this research, the writer proposed to test whether there was an effect of using multimedia reading materials on students' reading comprehension of narrative texts. The writer used quasi experimental design, the design of pre-test and post-test which used two groups as sample. The research 
was conducted in March 2019 at State Senior High School 12 Pekanbaru.

The number of the population is 391 students. Considering the population of this research is large, the researcher used Cluster random sampling to take the sample. The samples of this research are the students of X.1 as experimental class and X.3 as control class which both consisted of 70 students.

This research used quasi experimental design. In conducting the research, the writer conducted try out to test the validity and reliability test items. The test that was used in collecting the data of the research was multiple choice questions that consisted of twenty items and short-answer question consisted of five items. The questions were made based on indicators that were stated in syllabus which used by State Senior High School 12 Pekanbaru.

After testing validity and reliability, the writer conducted pretest and posttest in both of experimental and control class. The treatment was given in experimental class. After completing the research, the data was analyzed through Independent Sample T-test formula by using SPSS 25 Version.

The data was collected by using test. The test was used to find out the students' reading comprehension. The test was multiple choice questions that consisted of 20 items and short-answer question consisted of 5 items. The data of this research were the score of the students' reading comprehension obtained by using test.

The data was analyzed by using independent samples t-test formula calculated by using SPSS and continued by calculating effect size using eta square formula.

\section{Research Finding}

To examine the effect of using multimedia reading materials on students' reading comprehension, the writer analyzed the data by using independent sample t-test formula calculated by using SPSS. The result showed that sig. value is 0.000 . It can be stated that $0.000<0.05$. It means there is statistically difference between experimental and control class.

Then, to identify the level of the effect of using Multimedia Reading Materials on students' reading comprehension of narrative text at State Senior High School 12 Pekanbaru, it was calculated by using eta squared formula. The result showed that the effect size is 0.41 categorized into moderate effect. It means that the use of Multimedia Reading Materials has moderate effect on students' reading comprehension of narrative text.

Then, to know the biggest effect, the writer calculated its effect on each component by using SPSS. The result showed that only second component (identifying specific information of texts) and fourth component (identifying meaning of words in texts) which have statistically difference. So, the writer only need to find out the effect on second and fourth component.

To identify the level of the effect it was calculated by using eta squared formula. The result showed the effect size was 0 . It means the use of Multimedia Reading Materials has 
moderate effect on second component and large effect on fourth component of reading comprehension of narrative text. In conclusion, the use of Multimedia Reading Materials at State Senior High School 12 Pekanbaru has the biggest effect on fourth component of students' reading comprehension that is identifying meaning of words in texts.

Before examining the effect of using Multimedia Reading Materials on students' reading comprehension of narrative text at Senior High School 12 Pekanbaru, the writer calculated the mean, standard deviation and standard error mean of experimental and control class by using SPSS, can be seen in the following table:

Descriptive Statistics

\begin{tabular}{lccc}
\hline & & Experimental Group & Control Group \\
\hline $\mathrm{N}$ & Valid & 35 & 35 \\
& Missing & 0 & 0 \\
Mean & & 81.57 & 69.69 \\
Median & 82.00 & 73.00 \\
Mode & 80 & 67 \\
Std. Deviation & 4.779 & 8.993 \\
Variance & 22.840 & 80.869 \\
Range & 20 & 40 \\
Minimum & 69 & 44 \\
Maximum & 89 & 84 \\
Sum & 2855 & 2439 \\
\hline
\end{tabular}


Siswandi - An Experimental Study: Multimedia Reading Materials ...
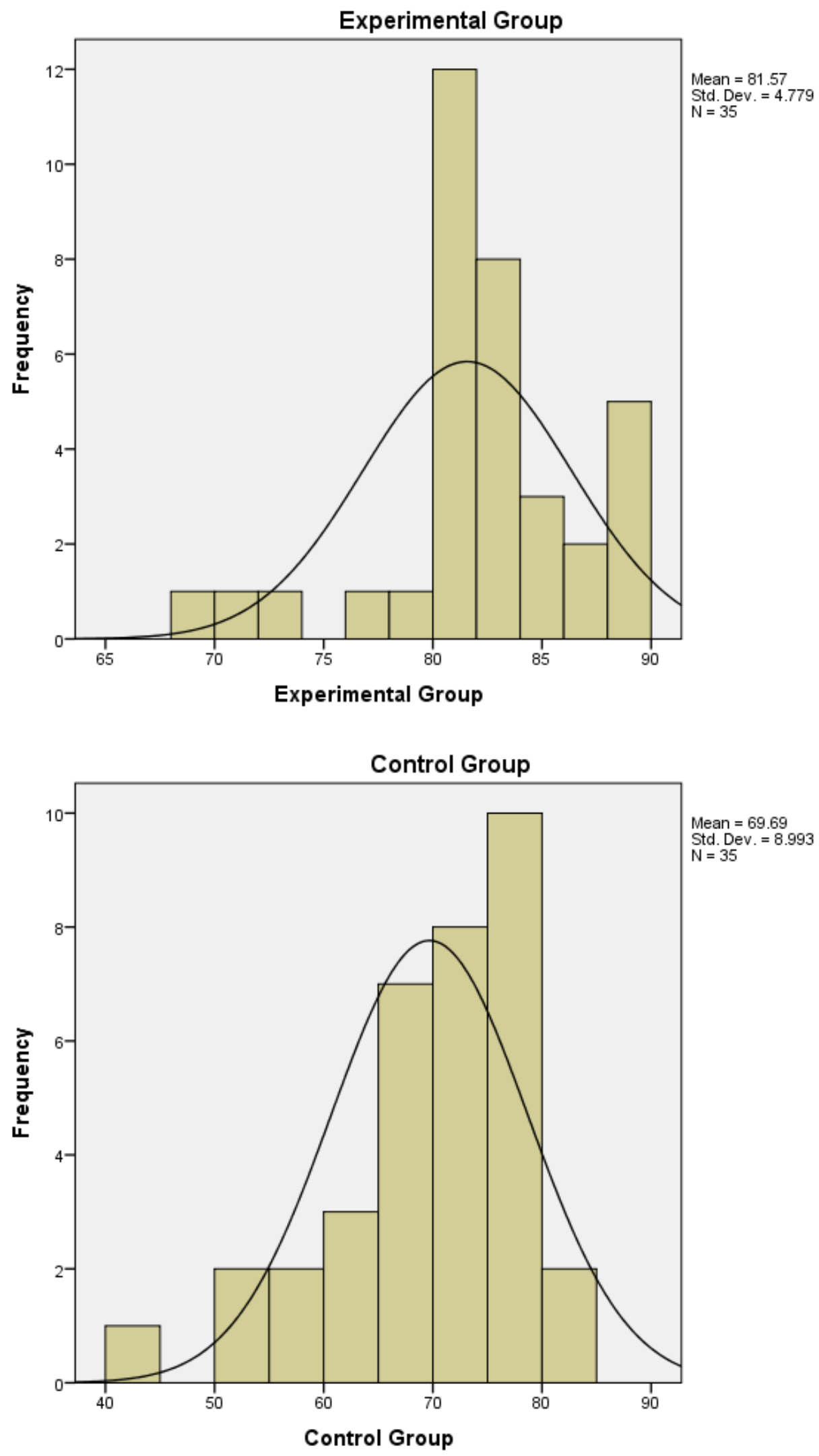
Based on the table above, the total number of students for experimental class consisted of 35 students and control class consisted of 35 students. The mean score of experimental class was 81.57 and the mean score of control class was 69.69 , and the standard deviation of experimental class was 4.779 , while standard deviation of control class was 8.993, the std. error of mean of experimental class was 0.72 , while the std. error of mean of control class was 1.03. The second table determines the result of the independent sample test analysis. The table is as follows:

\begin{tabular}{|c|c|c|c|c|c|c|c|c|c|c|}
\hline & & \multicolumn{4}{|c|}{$\begin{array}{c}\text { Levene's Test } \\
\text { for Equality of } \\
\text { Variances } \\
\end{array}$} & \multicolumn{3}{|c|}{ t-test for Equality of Means } & \multirow{2}{*}{\multicolumn{2}{|c|}{$\begin{array}{l}95 \% \text { Confidence } \\
\text { Interval of the } \\
\text { Difference }\end{array}$}} \\
\hline & & \multirow[b]{2}{*}{$\mathbf{F}$} & \multirow[b]{2}{*}{ Sig. } & \multirow[b]{2}{*}{$\mathbf{t}$} & \multirow[b]{2}{*}{ df } & \multirow[b]{2}{*}{$\begin{array}{l}\text { Sig. (2- } \\
\text { tailed) }\end{array}$} & \multirow[b]{2}{*}{$\begin{array}{c}\text { Mean } \\
\text { Difference }\end{array}$} & \multirow[b]{2}{*}{$\begin{array}{l}\text { Std. Error } \\
\text { Difference }\end{array}$} & & \\
\hline & & & & & & & & & Lower & Upper \\
\hline $\begin{array}{l}\text { Reading } \\
\text { Comprehension }\end{array}$ & $\begin{array}{l}\text { Equal } \\
\text { variances } \\
\text { assumed }\end{array}$ & 11.97 & .001 & 6.91 & 68 & .000 & 11.89 & 1.72 & 8.45 & 15.32 \\
\hline & $\begin{array}{l}\text { Equal } \\
\text { variances } \\
\text { not assumed }\end{array}$ & & & 6.91 & 51.79 & .000 & 11.89 & 1.72 & 8.43 & 15.34 \\
\hline
\end{tabular}

Based on research finding which has already discussed above, it can be concluded that the use of Multimedia Reading Materials has important role in improving students' vocabulary knowledge which also can improve their reading comprehension.

Finally, this research is expected can give valuable reference for the next researchers who are interested in carrying out a research in similar discussion topic.

\section{BIBLIOGRAPHY}

Anderson, N. J. (2003). Teaching Reading. In D. Nunan (Ed.), Practical English language teaching (pp. 67-86). New York: McGraw Hill Publishers.
Brown, H. D. (2004). Language Assessment: Principles and Classroom Practices. San Fransisco: Longman.

Cohen, L., Manion, L., \& Morrison, K. (2007). Research Methods in Education (Sixth Edit). New York: Routledge.

Creswell, J. W. (2012). Educational Research: Planning, Conducting, and Evaluating Quantitative and Qualitative Research. Educational Research (Vol. 4). Boston: Pearson Education, Inc.

Gay, L. R., Mills, G. E., \& Airasian, P. (2012). Educational Research: Competencies for Analysis and Applications (Tenth). United States: Pearson Education, Inc. http://doi.org/10.1017/CBO978110 
7415324.004

Grabe, W. (1991). Current Developments in Second Language Reading Research. TESOL Quarterly Quarterly, 25(3), 375406.

Hosea, B. (2006). The Focal Easy Guide to Macromedia Flash 8 (Vol. 1). Burlington: Focal Press. http://doi.org/10.1017/CBO978110 7415324.004

Mayer, R. E. (2005). Multimedia Learning (Second Ed). New York: Cambridge University Press. http://doi.org/10.1017/CBO978110 7415324.004

Moreillon, J. (2007). Collaborative Strategies for Teaching Reading Comprehension. Chicago: American Library Association.

Pandey, D. M. (2014). The Use of the Multimedia in the Teaching and Learning of English Language.

Rai, A. (2014). Role of Multimedia Laboratories in Language Teaching. IRC'S International Journal of Multidisciplinary Research in Social \& Management Sciences, 2(3), 154-156.

Richards, J., \& Schmidt, R. W. (2010). Longman Dictionary of Language Teaching \& Applied Linguistics (Fourth). London: Pearson Education Limited.

Saputra, H. J. A., \& Tiarina, Y. (2013). Using Macromedia Flas 8 to Help English Teacher to Build Media Toward Teaching Reading. Journal of English Language Teaching, 1. 